\title{
The Nishorgo Support Project, the Lawachara National Park, and the Chevron seismic survey: forest conservation or energy procurement in Bangladesh?
}

\author{
Mohammad Tanzimuddin Khan \\ University of New England, Australia ${ }^{1}$
}

\section{Introduction}

There is a relationship between neoliberal reform and new forms of environmental governance. Neoliberalism is a political project to increase the scope for capital investment and accumulation, by re-working state-market-civil society relations. It continues the historical process of commodifying nature that has been underway since the introduction of Locke's 'laissez faire' capitalism (Heynen et.al. 2007, p.10). Neoliberalism is both cause and consequence of the "reconfiguration of socio-natural systems" (ibid). As part of this reconfiguration, the participation by non-state actors (mainly involving communities and civil society/nongovernmental organisations) into natural resource management regimes reflects a new phase in the transition of global political governance into new forms of 'hybrid governance' or 'network governance' where multiple actors now play a role in environmental regimes.

The concept of governance has also changed with the controversies surrounding state-centric and market-driven approaches. in the developing world, disappointment over the Structural Adjustment programs of the Bretton Woods institutions in tackling the global debt crisis of the 1980s prompted policymakers to integrate more stakeholder participation in the development of national Poverty Reduction Strategy Papers (PRSPs), which henceforth controlled their loan programs. To understand this innovation in governance, the political economist Kanishka Jayasuriya $(2007,2008)$ proposes the idea of 'accountability communities'. According to him, participation of both state and non-state actors in governance gives birth to "accountability communities" that "constitute a public domain which shapes the organization of political authority that is crucial to the activities of governing" (Jayasuriya 2007, p.8). He further cautions that "accountability remains anchored to specific technical or instrumental goals of the transnational policy regimes..."(ibid, p.2); that participation does not really result in a truly non-hierarchical and democratic policymaking process.

Against this theoretical background, this paper offers an assessment of the USAID-sponsored Nishorgo Support Project (here in after Nishorgo Project), a forest conservation venture operating at the protected areas of Bangladesh. This project involves the participation of states, local communities and NGOs creating 'accountability communities', and we can assess how these emerge and operate.

This assessment will mainly focus on a particular event - in fact, a critical moment - for conservation in the Lawachhara National Park, Moulvibazar District, in Bangladesh. It is a critical moment in the sense that it offers us unique access to the unfolding interplay between the actors around which political authority of these 'accountability communities' was established. The moment occurred when Chevron, a US based multinational energy company, undertook a seismic survey within the area falling under the jurisdiction of the project in early 2008, thereby creating a fissure between the interests of conservation and energy procurement. ${ }^{2}$ The study enables us to investigate how strongly or weakly the participating actors of Nishorgo are tied to the declared goal of forest conservation, and how this commitment plays out.

\section{The Nishorgo project in Bangladesh}

This section briefly discusses the Nishorgo project, its locational aspects and the actors taking part in the project. This USAID (United States Assistance for International Development) sponsored project was launched in February 2004 in the Bhawal National Park, Tangail district, Bangladesh. Nishorgo's official aim is to develop and implement a co-management approach to conserve the Protected Areas of Bangladesh. The concept of co-management is defined as "a situation in which two or more social actors negotiate, define and guarantee amongst themselves a fair sharing of the management functions, entitlements and responsibilities for a given territory, area or set of natural resources" (Borrini-Feyerabend et.al., 2000, p.1). Such an approach to

\footnotetext{
${ }^{1} \mathrm{PhD}$ student, University of New England, Australia. mkhan34 "at" une.edu.au or tanzim04 "at" gmail.com. The study was conducted while a faculty member of the Department of International Relations, University of Dhaka, Bangladesh. I express sincere gratitude to my supervisor Dr. Tony Lynch, School of Humanities, University of New England for making valuable comments and editing the paper. Thank you also to two referees and the JPE editor. The article builds on an earlier working paper (Khan 2008).

${ }^{2}$ Seismic surveys are geophysical prospecting techniques that map the subsurface and allow for gas and oil to be pinpointed. Chevron Bangladesh exploded dynamite underground, resulting in vibration that is picked up by sensors. The survey needed access roads for heavy equipment, seismic survey lines, and drilling sites. The technique can cause physical damage to habitat including deforestation, de-vegetation, erosion and watercourse siltation, and disrupted drainage patterns.
} 
resource management is globally advocated by the International Union for Conservation of Nature (IUCN) and has received widespread application as well as critical discussion (Fabricus, 2004).

The proposed implementation of a co-management approach did have a precedent in Bangladesh. In September 2000 the Government signed the Tropical Forest Conservation Fund Agreement (TFCFA) with the United States Government. $^{3}$ Under the agreement, a debt-for-nature swap took place, and the United States transferred its first funds in 2004 to protect biodiversity of tropical forests (Withanage 2004). To this end, an independent grant-making institution called the Arannyak Foundation was established in Bangladesh. ${ }^{4}$

Nishorgo came into being in the same year. It operates in five different pilot sites of north-east Bangladesh. These sites are located in the Lawachhara National Park (Fig.1), the Rema-Kalenga Wildlife Sanctuary, and the Satchari Reserve Forest, Chunati Wildlife Sanctuary, and Teknaf Game Reserve (Fig. 1). All these sites are in the Surma Basin. This basin is identified as the Eastern fold belt, broadly covering the Chittagong-Tripura fold. In 2001 this fold belt area was also identified as the most prosperous gas reserve in Bangladesh, in a joint survey by Petro-Bangla and US Geological Survey (US Geological Survey-Bangladesh Gas Assessment Team 2001, pp. 2-9). ${ }^{5}$

Chevron Bangladesh carried out exploration for gas reserves in some of those areas identified in the survey. It conducted a seismic survey from March-June of 2008 for assessing the gas reserve in block-14 of Moulvibazar, part of which falls within the Lawachhara National Park. ${ }^{6}$ This National Park is recognised by the government of Bangladesh as one of the country's most vulnerable forests, and thus it is heavily protected.
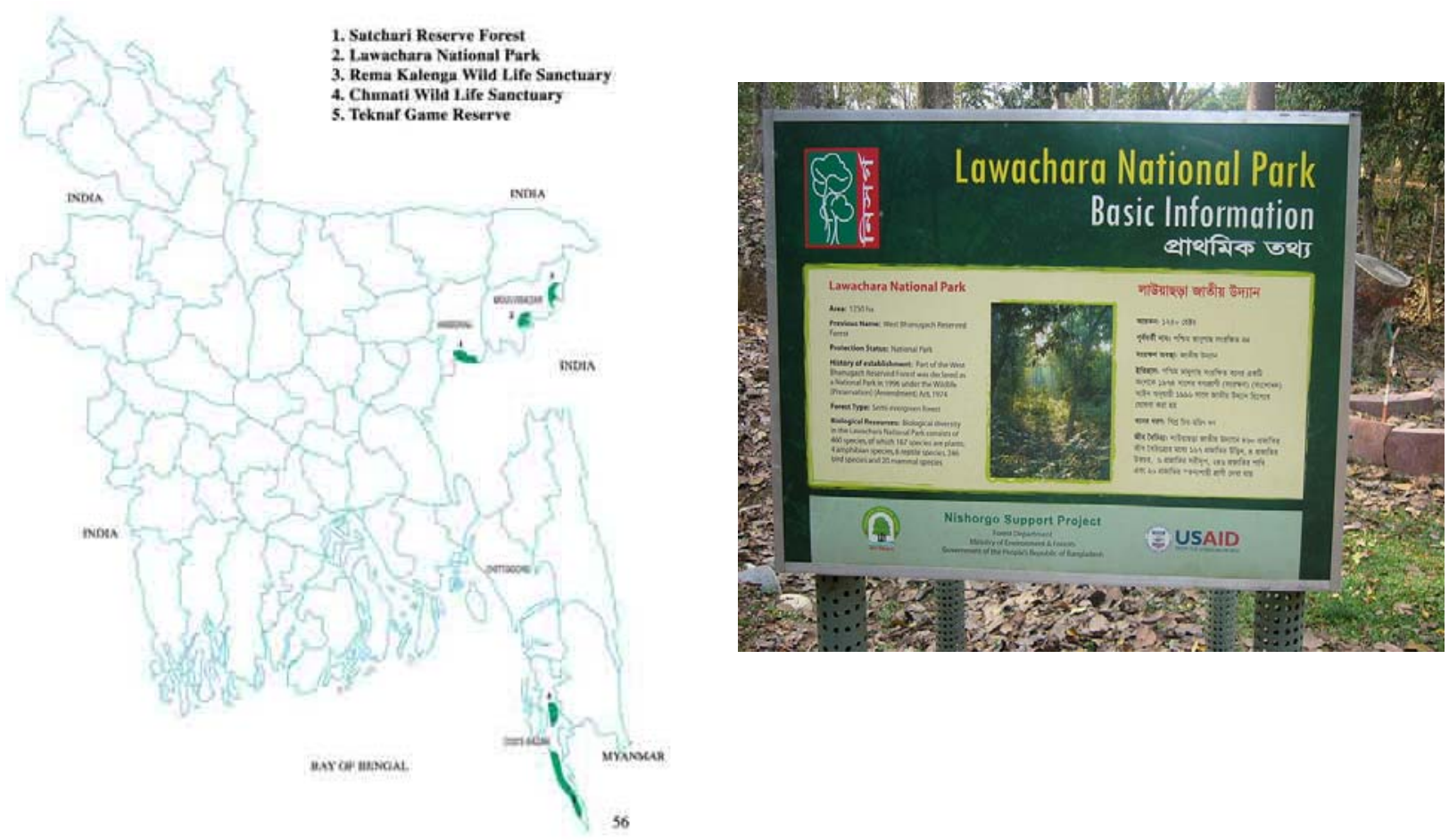

Fig. 1: Lawachara National Park in Bangladesh (no.2) and Park signboard. Source: IRG 2004 and public domain.

\footnotetext{
${ }^{3}$ In Bangladesh, the Tropical Forest Conservation Act dates from 1998 (105 US C 214 of 29.07.1998). It is an amendment to the Foreign Assistance Act (22 US C2151) of the USA, for facilitating the protection of tropical forests through debt reduction.

${ }^{4}$ Arannyak has the mandate to mobilize resources in the form of grants, loans and contributions from international donors, multinational companies, the Government of Bangladesh, private individuals and organizations. Its Board of Directors comprise members from USAID, the Ministry of Environment \& Forests (MoEF), and from several non-governmental organizations. International Resources Group (IRG), a Washington based consultancy organisation is a consulting firm for the project (http://www.arannayk.org)

${ }^{5}$ Petro-Bangla is a Bangladeshi state-owned oil and gas exploration company, while the US Geological Survey operates under the Department of Interior of the USA.

$6152 \mathrm{~km}^{2}$ of Moulvibazar and Srimangal districts were surveyed by Chevron.
} 


\section{The participating actors}

The application of the co-management approach for forest conservation in Bangladesh has involved incorporation of the local communities, state functionnaries and NGOs, along with USAID, which implements official development programs. From the Bangladesh government are the Ministry of Environment and Forest (MoEF), its Department of Forest of Bangladesh (DoF), and local governments.

Among the non-governmental entities, the Washington-based consulting organization the International Resources Group (IRG) has been nominated by the USAID as an implementing partner, and IUCN Bangladesh is an official consultant and stakeholder for the five year long project. A representative of IRG is the designated chief of party and heads the Nishorgo Support Unit, which is located inside the Dhaka Office of the DoF. S/he provides overall technical and advisory support in implementing the official programmes of the project

Three Bangladesh NGOs are also taking part. These are the Community Development Center (CODEC) of Chittagong, Nature Conservation and Management (NACOM), and Rangpur-Dinajpur Rural Service (RDRS), subcontracted by the IRG. The Wildlife Trust Bangladesh (WTB) is also a partner and stakeholder. The Bangladesh Environmental Lawyers Association (BELA) joined the project in 2007 to update the existing Wild Life Preservation Act 1974 (amended) for the implementation of the project.

The participation of the local communities, local government and the DoF in the project has been guaranteed with the formation of a two tiered co-management body. This local level body is officially responsible for conserving the forest, developing alternative livelihoods for local people, and ensuring the welfare of the forest and forest people. This body is designated as 'the guardian of forest'. Its lower tier is called the co-management council (CM council) and is authorised to hold general discussion on relevant issues and to make soft recommendations. Members of local communities are offered general membership in the CM council. However only local elites, local government officials and forest officials can join the upper tier of the co-management body, which is known as the co-management committee (CMC). The Assistant Conservator of Forest (Wildlife), DoF, is the member secretary of the CMC.

\section{The seismic survey, the critical moment and the interplay of the actors}

The seismic survey done by Chevron in the Lawachhara National Park pushed the whole project into a critical moment. Firstly, the survey, including the detonation of explosives, was conducted in violation of Article $23(3)^{7}$ of the Wild Life Preservation Act 1974 (Amended) of Bangladesh. Article 23 prohibits such activities within a one mile radius of the forest boundary. Secondly, the survey coincided with the main breeding season for plants and wildlife, prior to the monsoon. Given this, the role of the Nishorgo project both in dealing with the seismic survey, and its capacity to fulfil its overall conservational role - was questioned. Protected Areas should involve both state actors and non-state actors in forming 'accountability communities'. The following section focuses on how these communities responded to the Chevron seismic survey, before looking at how they managed their conservational responsibilities.

The DoF and the Ministry

A meeting between Chevron and the Ministry of Energy was held in September 2007, but the report on a possible seismic survey came to public attention for the first time in January 2008, when a Srimangal-based local newspaper published it (The Weekly Porikroma, 20 January 2008). According to the Divisional forest conservator (Wildlife Management and Nature Preservation Department) of Sylhet, the DoF was not informed of the issue at the outset (The Daily Star, 22 February, 2008). ${ }^{8}$ The DoF reacted only when the report on Chevron's seismic survey in Lawachhara Forest began to be published in the news media. In February 2008 they sent a letter to their Parent Ministry, the MoEF, to express their concern. However the MoEF, without taking this into account, issued a Gazette Notification in consultation with the Ministry of Law. This notification allowed the suspension of the Article 23(3) of the existing Wild Life Act on the grounds of 'public interest' (Gain 2008, p. 68).

The MoEF also issued a clearance certificate to Chevron so that it could undertake the survey in the forest (The Daily Star, 22 February 2008; The Weekly Porikroma, 18-28 March 2008; The Daily Prothom Alo, 16 May 2008). Further, it approved Chevron's Initial Environmental Examination (IEE) and Environmental Impact Assessment (EIA) which are the required conditions for undertaking such a survey. It was the responsibility of the Department of Environment (DoE) to make sure that the organization planning to conduct a seismic survey submits an IEE and EIA before the issuance of any clearance certificate (The Daily Star, 22 February 2008). However, it was not clear whether these two reports were submitted before the commencement

\footnotetext{
7 Article 23 (3) of the Act reads: "The Government may declare any area to be a national park where the following acts shall not be allowed, namely: (i) hunting, killing or capturing any wild animal in a national park and within the radius of one mile outside its boundary; (ii) firing any gun or doing any other act which may disturb any wild animal or doing any act which may interfere with the breeding places of any wild animal; (iii) feeling, tapping, burning or in any way damaging or destroying, taking, collecting or removing any plant or tree therefrom; (iv) clearing or breaking up any land for cultivation, mining or for any other purpose; ( $v$ ) polluting water flowing in and through the national park...."

8 Md Abul Basar Miah.
} 
of the survey as Chevron's reports were never made public. On the contrary, prior to the issuance of this Gazette Notification, the Secretary for the MoE remarked that the survey would not go against the national interest of Bangladesh and would not violate the Act of 1974 (The Weekly Chaer Desh, 22 January 2008).

Following the media attention, public concern over Lawchhara Forest grew and so the MoEF formed a monitoring team to assess the environmental impacts of the seismic survey. The twelve member team had representation from the IUCN, BELA, DoE, DoF, Petrobangla, Chevron, and Grant ${ }^{9}$ (The Weekly Chaer Desh, 2 April 2008). The most disturbing and interesting part of this monitoring team was that Chevron itself provided the necessary financial support for assessing its own environmental impacts.

\section{Local government}

Local governments in the area, officially part of the co-management body, took action only when the local Upazila Nirbahi (sub-district executive) Officer formed a five-member investigation committee at the insistence of the District Commissioner. This committee was formed in order to assess the damage of a Khasia punji (village) (located inside the forest) where a fire took place during Chevron's survey. The report of the committee dif little - it actually provided the necessary basis for the Deputy Commissioner of Moulvibazar district to allow Chevron to resume its seismic survey in April 2008. ${ }^{10}$

The co-management body

The co-management body did not take any official position in response to the seismic survey, and did not discuss the issue at any level either until the last week of May 2008. When the committee officially responded, the Chevron survey was almost complete. ${ }^{11}$ On the $29^{\text {the }}$ May 2008, the chairman of the CMC sent a letter to the President of Chevron expressing concern that they were hiding the 'practical aspects' and 'true information' related to the environmental impacts of the survey. The CMC of Lawachhara Forest condemned the energy company for ignoring the issue of biodiversity protection and the 'interests of the local communities', and alleged that Chevron had failed to hold a 'formal official meeting' with them before conducting the seismic survey. In reply, Chevron denied the allegation and claimed that they had held 'two meetings' with the committee in March and April of 2008. Chevron's reply was not accompanied by any documents recording the official minutes of the 'two meetings'.

Nevertheless, in a personal interview with me, the Vice-Chairman of the CMC reaffirmed that the Committee "had these two meetings" but in the presence of the members who hailed only from Kamalganj area; members from Srimangal area were absent. Thus, the CMC did not have a clear or unified position on the issue of the seismic survey conducted in the Forest. Further, while the survey was ongoing, the co-management body's attentions were elsewhere, focussed on holding elections through secret ballot to elect their 19 executive members for the CMC. ${ }^{12}$

Nishorgo Support Unit

The Nishorgo Support Unit, headed by the IRG, did not seem to take any official position, nor express any concern over the seismic survey in the Lawachhara National Park. In the same manner, other subcontracted partners - NACOM, RDRS and CODEC of Chittagong - also remained silent. The USAID Environment Team Leader commented that they had nothing to do with the seismic survey as the DoF and DoE had already authorised Chevron Bangladesh to operate within Lawachhara National Park (The Weekly Porikroma, 12 May 2008).

\section{The IUCN, BELA and the WTB}

IUCN, WTB and BELA's reaction to the seismic survey was confounding. Their perceptions on the probable impact of seismic survey did not differ from Chevron's - that it would do no harm. With regard to the prospect of filing a public litigation case against Chevron for violating the 1974 Act, BELA expressed their lack of confidence on the grounds that "if BELA loses the case in the court, it would give Chevron a legal ground for conducting the survey"'13. But like USAID, all the consulting NGOs working in the project under different capacities placed the blame on the government for allowing Chevron to conduct the survey in the first place. ${ }^{14}$

Not withstanding this, BELA was active in its opposition at the grass roots. They held several street protests against the survey and submitted a Notice of Concern to the government along with some other Dhaka-

\footnotetext{
9 A company subcontracted by Chevron to do the seismic survey.

10 The letter was issued on 30 April 2008 vide No. jaypromou/L.A-56(ongsho-1)/2008/191.

11 It was disclosed in a Focus Group Discussion with the President, Secretary, Treasurer and others, held on 13 June 2008. Gidison Prodhan, the tribe chief of Magurchhara Punji was also interviewed. The author is in receipt of the minutes of the monthly meetings of the Co-management Council from January to May 2008.

12 The election was held on 17 April 2008. Minutes of the Co-management Committee meeting, held on 20 April 2008.

13 Rizwana Hasan, the Programme Director of BELA in a recorded interview with the author, on 15 June 2008.

14 Opined by the IUCN's country representative- Ainun Nishat, a recorded interviews taken on 15 June 2008 ; WTB's Executive Director- Md. Zakir Hossain in a telephonic interview with the author, taken on the 15 June, 16 June and 17 June 2008 respectively.
} 
based NGOs in April 2008 (The Daily Star, 7 April 2008). ${ }^{15}$ The BELA local office in Srimangal also organised and participated in a number of 'human chains' held in protest against the seismic survey at the Lawachhara National Park, along with other local organisations (The Daily Star, 6 March 2008).

\section{The declared goal of the project, and the operational reality}

With the declared goal of conserving the unique biodiversity of the protected areas, the Nishorgo project is committed to reducing the dependence of the forest dwelling communities on the forest by facilitating alternative sustainable livelihoods. This section examines these sustainable livelihood strategies. The promotion of eco-tourism and non-timber industries for the communities living inside or close to protected areas is one of the major constituents of this effort (IRG 2006, p.16). The CMC of the Nishorgo project is also authorized to form forest patrol groups, and to distribute livestock to the group members to assist with income generation. These programmes are undertaken so as to create a sense of ownership and responsibility among local communities, thus bonding them to the project's goal of forest conservation.

For the successful implementation of ecotourism, designing an appropriate programme and strategy for adequate tourist facilities and understanding the culture of the forest dwelling communities in welcoming the tourists to the forest are important. It also requires limiting the number of visitors and their access to the environmentally sensitive locations, both for safety as well as for conservation (Guillemain et al 2007, pp. 3633-3651; López-Espinosa de los Monteros 2002, pp. 1539-1550; Belangar 2006; Ogutu 2002, pp. 251-256).

In the case of the Nishorgo Project, the arrangement for promoting ecotourism in Lawachchara Forest appears to be poorly managed. No inventory of the forest's resources (both living and non-living species) was done to determine whether the Forest is really suitable for commercially viable eco-tourism. The National Park has only some small patches of natural forest which provides refuge to the globally endangered species of hoolock gibbon (Bunopithecus hoolock), but it is only 1,250 hectres in size.

Nevertheless, with increasing media attention over the years, a good number of tourists are now visiting the Protected Area every year. According to the Information Center of Lawachhara Forest, in the first three months of 2008 there were an estimated 22,000 tourists. The Nishorgo Project at Lawachhara offers training as tour guides to the members of the local communities. Still, infrastructure for eco-tourism in Lawachhahra Forest is not well-developed and, indeed, far from satisfactory. The infrastructure includes a ticket counter cum information center, a make-shift tourist shop, signs, and a few tourist cottages (Fig.1). Even the DoF has expressed dissatisfaction with the existing infrastructure. The report published by the DoF observes that:

Under Nishorgo, the lack of a medium-to-long-term nature tourism development plan resulted in some trail development, refurbishing and enterprise-related investments not being as effective as they might have been (Forest Department 2007, p.13).

The authority is currently planning to build an expensive "interpretation centre" for tourists (Ahsan 2007, p.133). In the monthly meeting of the CMC of Lawachhara in May 2008, there was also a proposal to build a five star hotel in the area to cater to the needs of the tourists. The proposal was made by a member of the CMC who represents Manipuri community of Srimangal in the Nishorgo Project. ${ }^{16}$

The benefits of eco-tourism at Lawachhara are not evenly distributed. Only $19 \%$ of the households were found to benefit from it in 2007 (ibid). Among the three local indigenous groups (Khasia, Tripura and Manipuri), the Manipuri community is the major beneficiary of eco-tourism (43\% of the total households surveyed) followed by the Tripura (13\%) (ibid, pp. 140-141). The Khasia community, living inside the Protected Area, appears to be the most deprived, receiving the least benefit.

Furthermore, the chief of the Khasia punji, located inside the forest, alleges that outside visitors often do not respect the local culture. The tourists sometimes indiscriminately enter and damage betel leaf gardens. In Khasia culture betel leaf gardening has a very special place. Khasis do not enter and start working in a betel leaf garden without performing prior rituals like sanctifying the body with fresh water and wearing special clothes. According to the Khasia chief, the use of sound systems and tourist events disrupts the serenity of the forest and the forest dwellers. ${ }^{17}$

\section{Non-timber products}

As part of their programme, Nishorgo has promoted plantations, animal rearing, and micro-credit schemes for the local communities. The Rangpur-Dinajpur Rural Service (RDRS) is in charge of administering micro-credit and other livelihood programmes in the area. Under the plantation programme, the DoF encourages the plantation of the exotic species like eucalyptus, acacia, hybrid acacia, etc. in the buffer zones of

15 The other organizations are Association for Land Reform and Development, Ain O Shalish Kendro, Bangladesh Legal Aid and Services Trust. Nijera Kori, Odhikar and Paribesh Bachao Andolon

16 Proposal by Ananda Mohon Sinha. The author attended the CMC meeting as a participant observer. The meeting was held on 30 May 2008. The meeting was attended, among others, by the Chief of Party, a representative of International Resources Group (IRG) in Bangladesh.

17 Described on 29 May 2008 in a recorded interview. 
surrounding the Protected Areas so as to generate household income for the communities. Such plants can be easily grown and thus promise to be commercially beneficial. However this commercial plantation development is controversial on the grounds that it is not environment friendly and that involves the destruction of local species. Indeed the Asian Development Bank has recently ceased its practice of funding such projects in Bangladesh.

\section{Forest patrolling}

The CMC of Lawachhara runs three area-based patrolling groups to reduce incidents of illegal logging. Each patrolling group has 20 members. One of the groups is comprised only of female members. Members of the local communities joined the patrolling groups on the promise of work, even though several had previously been illegal loggers themselves. They joined the patrolling groups since the CMC members and the local officers of DoF promised that their pending charges for illegal tree felling would be withdrawn.

The group members were also offered a monthly honorarium of Taka 2,500 (US\$ 36.23) along with other livelihood support. At the time the author made his field visits, only eight members of the groups of Bagmara and Dulubari had received Taka 11,000 (US\$ 159.42) for buying cattle, and had not received their honorarium since December 2007. Moreover, a leader from the womens' patrolling group, Renu Begum, alleged that they had not received anything apart from uniforms and shoes for their patrols. Also, another group leader, Kalam Ahmed of Bagmara, informed me that they had individually received only Taka 2,250 per month in the first 12-15 months of the formation of the groups, and that for the next two months, prior to the eventual stoppage of the payment, they received only Taka 1,125. The president of the CMC contradicted this information, claiming that the amount had been Taka 2,250, not 1,125. He defended any non-payment of the allowance on the ground of fund shortage. To make the existing situation worse, the pending cases against the illegal tree fellers have not yet been withdrawn by the DoF. If anybody now refuses to guard the forest given the non-payment of honoraria, the DoF threatens them with arrest.

Under the circumstances, the usefulness of the patrolling groups in preventing illegal tree felling and thus conserving the forest has now been called into question. The Vice-Chairman of the CMC was of the opinion that the illegal tree felling had not significantly declined, rather the routes taken to extract timber had altered. An eco-tour guide working in the forest also made a similar statement, claiming that the stolen logs which used to be passed via Srimangal are now routed through the Rajnagar area. Optimistically, the President of the CMC claimed that the success rate of preventing illegal tree felling is more than $90 \%$.

Internal feuds within the patrolling groups also developed. For instance, the CMC expelled 12 former members from Baligaon from the patrolling groups without cause, and inducted new members to replace them. The Union Parishad (Council) chairman, from the same area, was also suspended from the CMC when he protested the expulsion. ${ }^{18}$ Given the feud within the CMC and a weak performance in delivering services, the members of the CM Council of the Co-management body lost their enthusiasm for attending the monthly meetings. The CMC of Lawachhara observed that among 58 members of the Council, only 21 members had regularly attended. As many as eight members of the council had never attended a single meeting. For the rest, attendance was irregular. ${ }^{19}$

\section{The implications of the project: conserving forest or procuring energy?}

Given our exploration of the 'critical moment' of the Chevron seismic survey, and the response to it by important actors, it seems reasonable to conclude that when a dilemma between forest conservation and energy exploration emerges, the 'accountability communities' of the state and non-state actors in the Nishorgo project are ill-equipped to effectively defend the integrity of their declared goal. It is also clear that government approval of Chevron's survey activities in the Lawachhara National Park, on the pretext of 'Public Interest', is highly controversial. A further concern is the under-performance of the programmes so far undertaken for creating alternative means for livelihood of the local communities, documented in the last section. As a result, attachment to the goal of conservation does not appear to be as strong as the project requires, and, in fact, seemed to be diminishing by 2008. In this context, a political ecology analysis would conclude that that the national interest in procuring energy and the business interests of a multinational company were prevailing over forest conservation.

It is important to ask why the involvement of USAID and the Bangladesh Government, along with the local communities and NGOs forming the 'accountability communities' in the Nishorgo Project, failed to deliver strong environmental outcomes. What went wrong? To properly understand these issues requires attention to the intrinsic relationship that already exists among the actors, and thus to the institutional framework of the project under which these actors are interacting. Indeed, the 'accountability communities' of the project share a common relationship outside the Nishorgo Project. More particularly, their relationship appears to be aligned with the corporate interest of Chevron. This section aims to substantiate these claims.

\footnotetext{
18 His name is Golam Kibria Shafi.

19 Minutes of the $5^{\text {th }}$ Meeting of the co-management committee.
} 
USAID implements development programmes in accordance with US foreign policy objectives, and is the major financial contributor of the Nishorgo Project. It has a Corporate Social Responsibility (CSR) agreement with Chevron. ${ }^{20}$ Under the agreement, Chevron Bangladesh delivers social services including health care facilities in the north-east of Bangladesh where the Nishorgo project operates. ${ }^{21}$ This partnership between Chevron and USAID is the result of the Global Development Alliance, which was part of USAID's business model, launched in 2001. ${ }^{22}$ The 2007 Strategic Plan also confirms the institutional merger of US security interests with that of the development assistance of USAID (US State Department and USAID 2007). In this regard, needless to say, energy is one of the sensitive components of US security and the CSR agreements between USAID and Chevron signify this aspect. ${ }^{23}$

Similarly, IUCN Bangladesh is a member of the Chevron-funded-monitoring team (founded in April 2008) and also an evaluator of the Environment Management Plan of Chevron Bangladesh. The country representative of IUCN Bangladesh defended this relationship by arguing that they conform to their headquarters' global policy. ${ }^{24}$ The IUCN's Head Office is, in fact, the recipient of Chevron's financial support. In 2006 it received an amount of Swiss CHK 48,953,000 (US\$46,286,875) from Chevron for its global implementation of the environmental programmes (IUCN, 2007: 10), and the US State Department also makes annual voluntary contributions to IUCN. ${ }^{25}$

For IRG, the US development consultancy and implementing partner of Nishorgo project, the story is no different. It too has a global business partnership with Chevron. ${ }^{26}$ The IUCN and IRG, the common partners of Chevron, also work together in many separate projects around the world in partnership with USAID (Gevers et al. 2008, pp. 122-123).

Among the national organisations involved in Nishorgo project, Wildlife Trust Bangladesh (WTB), the partner and stakeholder, is a member of the national committee of IUCN Bangladesh. So too is the Bangladesh Environmental Lawyers Association (BELA) which joined the project in 2007 as a consulting NGO to revise the existing Wild Life Preservation Act 1974 (amended). Nature Conservation and Management (NACOM), another subcontracted partner of IRG, is a member of the Board of Directors of the USAID-funded Arannayak Foundation Bangladesh.

The Vice- President of the CMC of Lawachhara is an editor and owner of a locally published weeklyChaer Desh (The Land of Tea). He is also the president of Srimangal Press Club. His weekly is supportive of the seismic survey of Chevron in Lawachhara. ${ }^{27}$ In two of its issues, the weekly published a full page report and a separate investigative report suggesting the seismic survey would not have any negative consequences for the protected forest. ${ }^{28}$ On the other hand, the elected treasurer of the CMC, who is the executive director of a local NGO- Prantik, served IRG for two years as a local consultant.

Institutional Framework

The co-management body of Nishorgo, operating in the five pilot sites, has now been gazetted by the government. ${ }^{29}$ However, this Gazette Notification is fraught with inherent weaknesses in terms of the designated functions of the project. It recommends a uniform organisational and functional structure of the comanagement body for all five pilot sites, ignoring the existing geographical and demographic differences of the project areas. Surprisingly, the number of members and the functions of the co-management bodies of the Rema Kalenga Forest of Habiganj (with an area of only 850 ha) and Teknaf Game Forest (located in the extreme south of Bangladesh, covering an area of 11,615 hectares) are similar.

20 Chevron is the third largest American oil and gas company and a major contributor to the US economy. In 2007, it earned a net income of US\$ 18.7 billion, the highest annual earnings in its history (Chevron 2008: 1). It ranked third after the Altria Group and ExxonMobil in terms of the official monetary contributions made to the Republican and Democratic Parties of the USA during the years 1999-2006, and made donations of US\$48,097,350 from 2003-2010, largely to support individual ballot measures. http://www.followthemoney.org/press/ReportView.phtml?r=430\&ext=3.

${ }^{21}$ Two Smiling Sun Hospitals around Srimangal, Moulvibazar are operating, and many other social development programmes in the area have been undertaken under public-private partnerships. Chevron also built an Eidgah (open air mosque) at Baligaon, Kamalganj, Srimangal.

22 During the fiscal years 2002-2003, a total of 200 alliances were formed to create a fund of five billion US dollars in which partners would contribute US\$ 2.9 billion (USAID 2004, p. 35).

${ }^{23}$ Available at http://www.usaid.gov/about_usaid/primer.html, accessed on 12 July 2010. .

24 Ainun Nishat, country representative of the IUCN Bangladesh in a recorded interview taken by the author on 15 June 2008.

${ }^{25}$ Available at http://cms.iucn.org/about/union/donors/\#gov eaccessed on 12 July 2010.

${ }^{26}$ Available at http://www.irgltd.com/About_IRG/Clients.htm, accessed on 12 July 2010.

27 The author browsed all the issues published during January-June 2008.

${ }^{28}$ The first report on Onushondhani Protibedon [an Investigative Report], published on 2 April 2008; and the second report on Moulvibazar Fielday Chevroner Trimatric Vutattik Jorip [3-D Survey of Chevron at Moulvibazar Field], published on 14 April 2008.

${ }^{29}$ It was notified through a Government Gazette, No. pobom/porisha-4/nishorgo-64/(ongsho-4)/112. dated 07 August 2006. 
Also, surprisingly, women, who arguably bear the major brunt of livelihood challenges, have not been offered any guaranteed places on the CMC, which exercises the highest political power for decision making. The female members have a quota of 10 seats in the CM Council only, which operates more as a general assembly (Forest Department 2007, p. 13).

Participation of women has been encouraged in the livelihood programmes like forest patrolling, microcredit operation, nursery development, handicrafts making, etc. This approach of the project in getting women involved coincides with the community development tactic contained in the recommendations of a report prepared to ease the operation of the former UNOCAL Bangladesh Limited (UBL), another oil and gas company that was working in Moulvibazar district (Reyes and Begum, 2005). This report was written in response to the resistance that UBL had encountered over gas pipeline installation and land encroachment in Moulvibazar and Srimanagal. The absence of women leadership in the CMC of the Lawachhara forest resembles the guidelines of this report which suggests that, "female participation needs to occur in a culturally appropriate manner" (Ibid, p.17).

The participation of certain NGOs also appears to be very context driven, and not always in accordance with the general goal of the project. For instance, the engagement of BELA in particular resulted from a proposal made by the participants in a workshop in 2006 for bringing necessary modifications to the Act of 1974 (amended). ${ }^{30}$ Indeed, earlier, the UBL tried to get both BELA and IUCN involved for the supervision of their operation in Lawachhara. ${ }^{31}$ In response, BELA was 'hesitant' to engage itself as they were "discouraged... by the Ministry of Energy" and IUCN "felt that any formal monitoring or advisory role related to the Lawachhara Forest needed to be sanctioned by the Bangladeshi government..." (ibid: 27). The report reads:

...by not finding common ground with internationally recognized NGOs, reputable or not, UBL is fostering an adversarial environment where its every move is watched for the slightest sign of acting against the public interest, the environment or both (Reyes and Begum, 2005).

In this context, the report also gave emphasis to the need for engaging state machineries:

...the government should have a leading role with specific efforts being designed in a way that incorporates communities and requires their involvement. UBL, with its daily presence in gasaffected communities and its ties to government, could play a coordinating role helping communities prioritize genuine needs while identifying and reaching out to relevant government entities (ibid: 21).

The draft proposals for amending the Act and the participation of BELA came into being only when the government had formalised the project through the gazette notification. In effect, the USAID-friendly IRG, which is also a global working partner of Chevron, appears to have replaced the UBL in a functional sense. The one year budget of the project prepared in 2007 by IRG suggests this. The 2007 budget shows that the IRG got about $17 \%$ of the total budget (US\$1,906,825) for the five pilot sites, with $17 \%$. If the costs of the subcontracted partners (48\%) are taken into consideration, the total expenditure for consultancy and service delivery stands at $65 \%$ of the total. Finally $15.5 \%$ of the total budget remains for direct project costs (IRG 2007, p. 52).

The draft proposals for amending the Act of 1974 now aims to incorporate the idea of co-management for conserving the protected areas in Bangladesh. Accordingly, the draft proposes to legalise hunting of wild animals for, among other things, scientific research and when it is "necessary in the interest of scientific or any public purpose". ${ }^{32}$ The proposed draft also authorises to "enter or reside in a sanctuary", for "scientific research" and "ecotourism". ${ }^{33}$ But phrases like 'scientific research', 'scientific purpose', 'public purpose' and 'ecotourism' have not been defined in the draft. Only the co-management of the protected areas/sanctuaries has been termed as "collaborative management" ${ }^{34}$.

\footnotetext{
${ }^{30}$ Arranged by the CMC of Lawachhara and held from 29-31 May, 2006.

${ }^{31}$ Chevron Bangladesh took over the operation of UBL in 2005.

32 The draft proposal for amending the 1974 Act came into being only after the government had issued the gazette notification for the project. Citing Articles 7 and 9 of the draft Act.

${ }^{33}$ Article 18 of the Draft Amendment of Wild Life Act, 1974.

34 The proposed Article 19 reads: (1) The Chief Wildlife Warden...(s)he shall, (a) construct such roads, bridges, buildings, fences or barrier gates, boundary marks and carry out such other works as he may consider necessary for the purposes of better management of such sanctuary: Provided that no construction of commercial tourist lodges, hotels, zoos, eco-parks and safari parks shall be undertaken inside a sanctuary except having consent from the local community and with the prior approval of the Board and an environmental impact assessment; ...

Again, the article says:

The Government, in order to promote collaborative management... may frame appropriate rule through gazette notification,
} which shall include the following, amongst others;

(i) recognition (constitution) of collaborative management council/ committee for the purpose of protection, improved management and sustainable use of wildlife resources and habitat; 


\section{Concluding remarks}

The case of an exploratory seismic survey for natural gas in a National Park, and the failures of a comanaged forest conservation project, have been explored in order to understand a recent environmental project in Bangladesh. Different sources of evidence point to the conclusion that the forest conservation project based on 'co-management' has not been effective in meeting its stated goals, and that this failure may be explained through forces external to the region. It is not an unreasonable conclusion that the officially declared values, norms, and ideational elements which provide for the governance of the project may perhaps be covering up a complicity with resource exploration. Jayasuria's "accountability communities" do indeed remain anchored to "specific technical or instrumental goals of the transnational policy regimes..." (2007, p.2). In this regard, the 'critical moment' of the 2008 gas survey in a National Park has opened up a Pandora's Box. One must not be misled by only focusing on the normative framework of participatory governance that appeared to have been deployed. Certain universal values like transparency, participation, and accountability were in fact enacted for a purpose. To understand the complex dynamics of such a project, it is necessary to dig further to assess who is influencing who, and for what reason.

Attention should particularly be focussed on the political-economic interests that bind 'accountability communities' together. They exist in a network, and function and interact with each other across institutional boundaries. In the case of the Nishorgo Project, USAID appears to be tied, because of its mandate and commitment to public-private partnerships, to many of the business interests of Chevron. The Bangladesh state apparatus appears to have been drafted in as a facilitator of these interests, at least in the period 2007 to 2008 when the Chevron survey occurred. In addition, local communities, civil society organisations and consultancies (including IRG, IUCN, BELA, WTB and other NGOs involved in the project) have evidently become anchored to a lesser or greater extent to resource exploitation interests, even though their official missions should align them much more to forest conservation. In the words of Newell and Levy, an environmental project like Nishorgo that binds these actors together can be seen:

....as a strategy of accommodation, combining material and discursive efforts to preserve corporate legitimacy and autonomy in the face of growing public environmental concern; it is thus more about political and economic than environmental sustainability (Levy and Newell 2007, p. 93).

\section{References:}

Ahsan, Md. Madinul. 2007. Perceptions of tourism by indigenous community living in and adjoining Lawachara National Park. In J. Fox, B.R. Bushley, S. Dutt, S.A. Quazi (Eds.), Making conservation work: linking rural livelihoods and Protected Area management in Bangladesh. Honolulu \& Dhaka: East West Center and Nishorgo Program of the Bangladesh Forest Department, pp. 131-148.

Borrini-Feyerabend G., Farvar M.T., Nguinguiri J.C., Ndangang V. 2000. Co-management of natural resources: organizing negotiation and learning by doing. Heidelberg: Kasparek.

Belanger, Kevin. 2006. Ecotourism and its effects on native populations. Unpublished paper available at http://www.geog.umd.edu/academic/undergrad/harper/kbelanger.pdf (accessed 12 July 2010)

Chevron. 2008. Energy performance 2007: supplement to the Annual Report. California: Chevron Corporation Headquarters.

Fabricius, C. 2004. The fundamentals of community-based natural resource management. Pp. 3-43 in Fabricius C, E. Koch, H. Magome, and S. Turner (Eds.). Rights, resources and rural development: community-based natural resource management in southern Africa. London: Earthscan.

Forest Department. 2007. Lessons learned from co-management under Nishorgo and guidelines for adapting co-management to other Protected Forest Areas. Dhaka: Nishorgo Support Project. Available at http://www.Nishorgo.org/Nishorgo/files_pdf/Lessons_Learned_\&_Generalized_Co-Mgmt_ver4.pdf (accessed 12 July, 2010).

Gain, Philip. 2008. Lawachhara ebong seismic servey [Lawachhara and the Seismic Survey of Chevron]. The Daily Sangbad. 28 February 2008.

Gevers I, L. de Vries, M. Pabari, \& J. Woodhill. 2008. External review of IUCN 2007: report on linking practice to policy (Objective 3), Annex-2 of Vol. 1. Ontario: Mestor Associates and Weginingenur.

(ii) entering into an agreement with collaborative management council/ committee specifying rights and authorities of such council/ committee and also responsibility of such council /committee for protection, improved management and sustainable use of wildlife resources and habitat.... 
Guillemain M, R. Blanc, C. Lucas \& M. Lepley. 2007. Ecotourism disturbance to wildfowl in protected areas: historical, empirical and experimental approaches in the Camargue, Southern France. Biodiversity and Conservation 16: 3633-3651.

Heynen N, J. McCarthy, S. Prudham \& P. Robbins (Eds.) 2007. Neoliberal environments: false promises and unnatural consequences. London: Routledge.

IRG. 2004. Pre-assessment of enterprise development opportunities associated with pilot protected areas of the Nishorgo Support Project. Available at http://www.usaid.gov/bd/files/NSPPre_Assessment_of_Enterprise_Dev.pdf (accessed 12 July 2010).

IRG. 2007. Nishorgo Support Project 5th year work plan: June 1, 2007 through May 30, 2008, Dhaka: Nishorgo Support Unit, formerly available at http://www.Nishorgo.org/files_pdf/Year_5_Work_Plan_ver10.pdf. (accessed 2 April 2008).

IUCN. 2007. Consolidated financial report for the year ended December 31, 2006 and Auditors' Report. Gland, Switzerland: IUCN.

Jayasuriya K. 2007. Riding the accountability wave? Politics of global adminstrative law. Working Paper No. 142, Asia Research Centre, Murdoch University. Available at http://wwwarc.murdoch.edu.au/wp/wp142.pdf (accessed 12 July 2010)

Jayasuriya K. 2008. Retailing governance? The rise of accountability communities. Policy Brief 2, Asia Research Centre, Murdoch University. Available at http://wwwarc.murdoch.edu.au/wp/pb2.pdf

Khan, M.T. 2008. USAID’s Nishorgo Project and Chevron's seismic survey and Lawachhara National Park of Bangladesh: a critical review. Working Paper No. 256/08, Center for the Study of Globalisation and Regionalisation, University of Warwick.

Available at http://www2.warwick.ac.uk/fac/soc/csgr/research/workingpapers/2008/25608.pdf

Levy, D.L. and P.J. Newell. 2002. Business strategy and international environmental governance: toward a neoGramscian synthesis. Global Environmental Politics 2 (4): 84-101.

López-Espinosa de los Monteros, R. 2002. Evaluating ecotourism in natural Protected Areas of La Paz Bay, Baja California Sur, México: ecotourism or nature-based tourism? Biodiversity and Conservation 11(9): 1539-1550.

Ogutu, Z.A. 2002. The impact of ecotourism on livelihood and natural resource management in Eselenkei, Amboseli Ecosystem, Kenya. Land Degradation and Development, 13(2): 251-256.

Reyes, David and Sajeda Begum. 2005. Corporate engagement project field visit report: Unocal Bangladesh. Cambridge: CDA Corporate Learning Project, available at: http://cdainc.com/publications/cep/fieldvisits/cepVisit19Bangladesh.pdf (accessed 12 July 2010).

The Daily Prothom Alo, 16 May 2008

The Daily Star, 22 February, 2008

The Weekly Chaer Desh, 22 January 2008.

The Weekly Porikroma, 20 January 2008.

United States Agency for International Development (USAID). 1997. New partnership initiative: a strategic approach in development partnering. Washington, DC: USAID.

US Geological Survey-Bangladesh Gas Assessment Team. 2001. U.S. Geological Survey-PetroBangla Cooperative Assessment of Undiscovered Natural Gas Resources of Bangladesh: Petroleum Systems and Related Geologic Studies in Region-8, South Asia. U.S. Geological Survey Bulletin 2208-A. Available at http://pubs.usgs.gov/bul/b2208-a/b2208-a.pdf (accessed 12 July 2010).

US State Department and USAID. 2007. Strategic Plan: fiscal years 2007-2012. Washington: State Department and USAID, available at http://www.state.gov/s/d/rm/rls/dosstrat/2007/ (accessed 12 July 2010)

USAID. 2004. USAID business transformation. Washington: USAID. Formerly available at http://www.whitehouse.gov/results/agenda/report8-04/USAID.pdf and http://www.usaid.gov/about_usaid/bus_trans (accessed 10 May 2008).

Withanage, Hemantha. 2004. Forest in trouble: pros and cons of the US Tropical Forest Conservation Act Debt for Nature Swap Treatment. Nugegoda, Sri Lanka: Centre for Environmental Justice. 


\begin{abstract}
The paper focuses on the operation of a forest conservation project, the USAID-funded Nishorgo Support Project, and its operations in the Lawachhara National Park, Srimangal, Moulvibazar District, Bangladesh. The project has instituted a collaborative management approach. The participants include both state and non-state actors including the Bangladesh Government, the USAID, IUCN, NGOs, and local communities. In 2008 Chevron conducted a seismic survey for natural gas in the National Park, which violated municipal law. This placed the Nishorgo Project in a dilemma over its declared goal of forest conservation versus the interest of the state and Chevron in harnessing gas. This article analyses the interplay of the actors surrounding this critical moment, and argues the officially declared values, norms, and ideational elements guiding the project should be questioned. In establishing this argument, this paper uses the concept of "accountability communities" coined by Kanishka Jayasurya.
\end{abstract}

Key words: Accountability communities, co-management approach, Nishorgo Project, Chevron, USAID, conservation, participation, governance.

\title{
Résumé
}

L' article met l'accent sur le fonctionnement d'un projet de conservation des forêts, un projet d'appui Nishorgo financé par l'USAID, et de ses opérations dans le parc national Lawachhara, Srimangal, Moulvibazar District, au Bangladesh. Le projet a mis en place une approche de gestion participative. Les participants comprennent à la fois des acteurs étatiques et non étatiques, y compris le gouvernement du Bangladesh, de l'USAID, l'IUCN, les ONG et les communautés locales. En 2008, Chevron a réalisé une étude sismique pour le gaz naturel dans le Parc National, qui a violé le droit interne. Cela mettait le projet Nishorgo dans un dilemme sur son objectif déclaré de la conservation des forêts contre l'intérêt de l'Etat et Chevron dans l'exploitation du gaz. Cet article analyse l'interaction des acteurs autour de ce moment important, et fait valoir les valeurs officiellement déclarée, les normes, et des éléments «officiel» devraient être interrogés. En établissant cet argument, ce document utilise la notion de «communautés de responsabilité» de Kanishka Jayasurya.

Mots clés: «communautés de responsabilité», l'approche co-gestion, projet Nishorgo, Chevron, l'USAID, conservation, participation, gouvernance.

\section{Resumen}

El documento se centra en la gestión de un proyecto de conservación forestal, financiado por USAID Nishorgo Proyecto de Apoyo, y sus operaciones en el Parque Nacional Lawachhara, Srimangal, Moulvibazar Distrito, Bangladesh. El proyecto ha establecido un enfoque colaborativo de gestión. Los participantes incluyen tanto los actores estatales y no estatales, incluyendo al Gobierno de Bangladesh, la USAID, la UICN, ONG y comunidades locales. En 2008, Chevron realizó un levantamiento sísmico para el gas natural en el Parque Nacional, que violó la ley municipal. Esto colocó al Proyecto Nishorgo en un dilema acerca de su objetivo declarado de conservación de los bosques contra los intereses del Estado y de Chevron en el aprovechamiento de gas. Este artículo analiza la interacción de los actores en torno a este momento crítico, y sostiene los valores declarados oficialmente, las normas, y los elementos ideacionales conductor del proyecto debería ser cuestionada. Al establecer este argumento, este trabajo utiliza el concepto de 'comunidades de la rendición de cuentas' acuñado por Kanishka Jayasurya.

Palabras clave: comunidades de responsabilidades, el enfoque de la cogestión, Nishorgo proyecto, Chevron, la USAID, conservación, participación, gobernanza. 